\title{
PENGARUH RELIGIUSITAS KE-ISLAMAN TERHADAP PERTUMBUHAN EKONOMI DAERAH: BUKTI DATA PANEL KABUPATEN KOTA DI ACEH
}

\author{
Khairul Amri ${ }^{1}$; A. Rahmat Adi ${ }^{2}$ \\ Fakultas Ekonomi dan Bisnis Islam \\ Universitas Islam Negeri Ar-Raniry, Banda Aceh \\ E-mail : khairul.amri@ar-raniry.ac.id \\ diterima: 3/9/2020; direvisi: 15/1/2021; diterbitkan: 26/3/2021
}

\begin{abstract}
This study analyzes the effect of Islamic religiosity on economic growth. Measurement of Islamic religiosity using three dimensions consisting of a mosque quantity, Islamic boarding school (pesantren), and Islamic student (santri) quantity. Using panel data set of 23 districts in Aceh during the 2010-2017 period, the fixed effect approach-panel regression model, and Granger causality test were applied to test the relationship between variables. The study reveals that both mosques and santri have a significant effect on increasing economic growth. But, pesantren does not. Granger causality test indicates unidirectional causality from both mosques and santri to economic growth and pesantren. Unidirectional causality also running from economic growth to pesantren. In contrast, there is no causality relationship from economic growth to mosques, pesantren, and santri
\end{abstract}

Keywords: Economic growth, Islamic religiosity, Panel regression model, and Granger causality test

\section{PENDAHULUAN}

Pertumbuhan ekonomi sering dijadikan indikator keberhasilan pembangunan suatu perekonomian (Kanu \& Ozuruma, 2014). Pembangunan ekonomi dinilai berhasil ketika mampu memberikan dampak bagi peningkatan nilai produksi barang dan jasa di masyarakat, sehingga pendapatan masyarakat juga meningkat (Martin, 2019). Ketika pendapatan masyarakat tidak berubah, maka dalam kondisi tersebut dapat dikatakan bahwa ekonomi tidak tumbuh, sebaliknya dianggap menurun ketika pendapatan masyarakat mengalami penurunan (Amri, 2017). Dalam kontek daerah, pengukuran pertumbuhan ekonomi dapat diproxi dari pendapatan per kapita masyarakatnya. Peningkatan pendapatan per kapita mengindikasikan adanya pertumbuhan ekonomi. Semakin besar pendapatan per kapita, semakin baik pertumbuhan, dan kondisi tersebut mencerminkan adanya perbaikan tingkat kesejahteraan masyarakat di daerah yang bersangkutan.

Dalam satu dekade terakhir, pertumbuhan ekonomi daerah kabupaten kota di Aceh mengalami peningkatan Namun pertumbuhan tersebut relatif berbeda antar daerah, yang diindikasikan dengan adanya perbedaan pendapatan per kapita masyarakatnya. Di antara 23 kabupaten kota, hingga tahun 2016 daerah dengan PDRB per kapita tertinggi adalah Sabang sebesar Rp28,46 juta per tahun. Kemudian menyusul Aceh Barat sebesar Rp26,52 juta per tahun. Aceh Tengah dan Bireuen berada pada urutan ke tiga dan keempat dengan pendapatan per kapita per tahun masing-masing sebesar Rp20,29 juta dan sebesar Rp19,96 juta. Sebaliknya daerah dengan PDRB per kapita terendah adalah Subulussalam sebesar Rp5,24 juta per tahun, dan kemudian menyusul Pidie Jaya sebesar Rp 5,31 juta per tahun.

Pertumbuhan ekonomi suatu daerah dapat dipengaruhi oleh berbagai faktor seperti faktor politik (Alesina et al., 1996; Durham, 1999), kualitas 
Jurnal Ilmiah Ekonomi dan Bisnis

Vol. 18. No.1,Maret 2021 : 19-28

EISSN : $2442-9813$

ISSN : $1829-9822$

kelembagaan dan investasi (Adegboye et al., 2020), teknologi dan kesempatan kerja (Padhi, 2018), dan faktor sosial ekonomi lainnya (Castaño, 2007), bahkan religiusitas keagamaan juga dapat mempengaruhi pertumbuhan ekonomi (Narayanan, 2016; Basedau et al., 2018). Di antara sejumlah faktor seperti dikemukakan para peneliti di atas, keterkaitan antara religiusitas keagamaan terhadap pertumbuhan ekonomi masih menjadi kajian menarik. Apalagi, hingga saat ini, hasil penelitian empiris mengenai arah dan signifikansi hubungan antara dimensi-dimensi keagamaan dengan pertumbuhan ekonomi belum memberikan kesimpulan yang sama.

Dalam kontek Aceh, religiusitas keagamaan yang dimaksudkan adalah religiusitas keislaman. Hal ini disebabkan mayoritas penduduk Aceh adalah muslim. Sehingga nilai dan norma-norma yang berlaku di daerah tersebut termasuk dalam kegiatan ekonomi selalu dilandasi dengan nilai dan norma ke-islaman. Pemberlakuan syariat Islam secara kaffah di Aceh tidak hanya berhubungan dengan ibadah, tetapi juga dalam urusan muamalah terutama dalam aktivitas ekonomi masyarakat.

Hasil

kajian awal mengindikasikan bahwa tingkat religiusitas ke-islaman masyarakat di Aceh relatif berbeda antar daerah. Tingkat religiusitas suatu daerah dapat diproxi dari jumlah institusi keagamaan di daerah tersebut (Wang \& Lin, 2014). Dalam hal ini, pengukuran religiusitas didekati dengan pengukuran kuantitatif dengan menggunakan tiga dimensi yakni jumlah mesjid, institusi keagamaan termasuk lembaga pendidikan non formal seperti pasantren/dayah dan jumlah santri di masing-masing daerah. Jumlah mesjid dan pesantren di masingmasing daerah kabupaten kota di Aceh relatif berbeda. Demikian pula halnya dengan jumlah santri, juga berbeda antar daerah kabupaten kota.

Kajian mengenai keterkaitan religiusitas dan pertumbuhan ekonomi telah dilakukan oleh sejumlah peneliti. Namun kesimpulan yang mereka peroleh masih kontroversial, dan arah signifikansi hubungan antara kedua variabel tersebut masih menjadi pertanyaan terbuka. Seperti halnya hasil kajian Campante \& Yanagizawa-Drot (2013) menyimpulkan bahwa dalam masyarakat muslim, praktek keagamaan mempengaruhi pilihan pekerjaan yang dilakukan oleh masyarakat dan memiliki implikasi negatif terhadap kinerja perekonomian.

Berbeda dengan Campante \& Yanagizawa, penelitian yang dilakukan Wang \& Lin (2014) menyajikan bukti empiris bahwa tingkat religiusitas keagamaan memiliki peran penting dalam pembangunan ekonomi karena kepercayaan pada agama mempengaruhi preferensi politik, human capital dan etika kerja. Sejalan dengan Wang \& Lin, hasil kajian empiris yang dilakukan oleh Casimier et al. (2014) juga membuktikan bahwa dimensi religiusitas berpengaruh positif terhadap variabel sosial ekonomi.

Belum adanya kesimpulan yang sama mengenai keterkaitan antara religiusitas dengan pertumbuhan ekonomi, mengisyaratkan bahwa kajian mengenai hubungan kedua variabel tersebut masih penting untuk dilakukan. Apalagi dalam kontek Aceh, hingga saat ini kajian mengenai pertumbuhan ekonomi di daerah tersebut belum pernah dilakukan dengan menempatkan religiusitas keislaman sebagai predictor variable. Padahal, sebagai daerah penerapan syariat Islam, seluruh dimensi kehidupan masyarakat menjadikan nilai dan norma ke-islaman sebagai rujukannya baik yang berhubungan dengan ibadah maupun urusan muamalah.

Berbeda dengan sejumlah penelitian terkait, penelitian ini tidak hanya menguji arah dan signifikansi 
pengaruh dimensi religiusitas keislaman terhadap pertumbuhan ekonomi, tetapi juga menganalisis arah kausalitas antar variabel, sehingga temuan penelitian dapat menyajikan informasi mengenai apakah religiusitas keislaman menyebabkan pertumbuhan ekonomi, atau sebaliknya, pertumbuhan ekonomi yang mendorong religiusitas keislaman.

\section{TINJAUAN PUSTAKA}

Religiusitas keagamaan mempengaruhi kegiatan ekonomi masyarakat yang pada gilirannya berdampak pada pertumbuhan ekonomi. Hal ini disebabkan nilai dan norma agama yang dianut oleh masyarakat menjadi acuan bagi mereka dalam bersikap dan berperilaku termasuk dalam kegiatan ekonomi. Nilai keagamaan juga mempengaruhi pendidikan, kesehatan dan akumulasi modal manusia (Becker \& Woessmann, 2009). Selanjutnya akumulasi modal merupakan determinan penting pertumbuhan ekonomi (Amri \& Aimon, 2017). Hubungan kausalitas antara religiusitas dan pertumbuhan ekonomi dapat terjadi secara dua arah, dimana pertumbuhan ekonomi mempengaruhi religiusitas dan sebaliknya religiusitas juga dapat mempengaruhi pertumbuhan ekonomi (McCleary \& Barro, 2006; Wang \& Lin 2014).

Kajian empiris mengenai keterkaitan antara pertumbuhan ekonomi dan tingkat religiusitas masih memberikan kesimpulan yang kontroversial satu sama lain. Berawal dari penelitian Barro (2003) menganalisis keterkaitan antara agama dan pertumbuhan ekonomi dengan menggunakan data lintas negara. Penelitian tersebut menunjukkan bahwa pertumbuhan ekonomi berhubungan positif dengan tingkat religiusitas. Tingkat religiusitas mempengaruhi perilaku individu dalam kegiatan ekonomi. Semakin tinggi tingkat religiusitas seserang individu semakin tinggi pula kemauan untuk terlibat dalam kegiatan ekonomi. Temuan tersebut diperkuat dengan penelitian berikutnya oleh McCleary \& Barro (2006) bahwa tentang adanya kausalitas dua arah antara pertumbuhan ekonomi dan religiusitas.

Hubungan kausalitas antara kedua variabel tersebut juga dibuktikan oleh Wang \& Lin (2014) dalam kajian mereka menggunakan data panel provinsi di China. Mereka menemukan bahwa tingkat religiusitas keagamaan memiliki peran penting dalam pembangunan ekonomi karena kepercayaan pada agama mempengaruhi preferensi politik, human capital dan etika kerja. Tingkat religiusitas agama Kristen berpengaruh paling signifikan terhadap pertumbuhan ekonomi dibandingkan dengan religiusitas agama lainnya.

Berbeda dengan hasil penelitian empiris yang disimpulkan oleh beberapa peneliti di atas, Campante \& YanagizawaDrot (2013) menganalisis dampak ekonomi praktek keagamaan dalam konteks bulan Ramadhan di negara-negara muslim. Mereka menemukan bahwa praktek keagamaan mempengaruhi pilihan pekerjaan yang dilakukan oleh masyarakat dan memiliki implikasi negatif terhadap kinerja perekonomian. Penelitian Casimier et al. (2014) mengenai keterkaitan antara religiusitas dan sosial ekonomi mengindikasikan bahwa dimensi religiusitas berpengaruh terhadap variabel sosial ekonomi. Tingkat religiusitas suatu daerah berdampak pada kegiatan ekonomi masyarakat yang pada akhirnya menjadi determinan produksi barang dan jasa, sehingga berdampak pada pendapatan per kapita.

\section{METODE PENELITIAN}

Penelitian ini menggunakan data panel, yakni gabungan antara data runut waktu periode 2010-2017, dan data silang 23 kabupaten kota di Aceh. Keseluruhan data merupakan data sekunder yang 


\section{Jurnal Ilmiah Ekonomi dan Bisnis}

Vol. 18. No.1,Maret 2021 : 19-28

EISSN : $2442-9813$

ISSN : $1829-9822$

diambil dari laporan Badan Statistik Aceh. Fokus kajian ini dibatasi hanya pada religiusitas keislaman (islamic religiosity) dan pertumbuhan ekonomi. Tingkat religiusitas suatu daerah dapat diproxi dari jumlah institusi keagamaan di daerah tersebut (Wang \& Lin, 2014). Daerah dengan jumlah institusi keagamaan relatif lebih banyak mengindikasikan bahwa intensitas kegiatan keagamaan di daerah tersebut juga lebih tinggi, dan hal ini dapat merefleksikan tingkat religiusitas daerah itu sendiri. Kuantitas mesjid di suatu daerah merefleksikan intensitas kegiatan shalat berjemaah di daerah tersebut. Kuantitas pesantren dan santri di suatu daerah merefleksikan kesungguhan masyarakatnya dalam mendalami ilmu tentang Islam. Karena itu, dalam kajian ini dimensi mesjid diukur dengan jumlah mesjid per 10.000 jiwa penduduk, dimensi pesantren diukur berdasarkan jumlah pesantren per 20.000 jiwa penduduk dan selanjutnya dimensi santri diukur berdasarkan jumlah santri per 10.000 jiwa penduduk.

Mengingat penelitian ini menggunakan data panel, maka model ekonometrik regresi panel digunakan untuk mengestimasi arah dan signifikansi pengaruh antar variabel. Dalam hal ini, PDRB per kapita diposisikan sebagai variabel independen yang kemudian diprediksi menggunakan religiusitas keislaman dimensi masjid, pesantren dan dimensi santri sebagai predictor variables. Sehingga model ekonometrik yang merefleksikan hubungan fungsional antar variabel seperti dalam persamaan 1 .

$$
\begin{aligned}
& \operatorname{PDRB}_{\text {it }}=\beta_{Q}+\beta_{1} \mathrm{MSJ}_{\text {it }}+\beta_{2} \text { PSTR }_{\text {it }}+\beta_{3} \mathrm{STR}_{\text {it }}+ \\
& e_{\text {it }}
\end{aligned}
$$

Dimana, $\beta_{0}$ adalah konstanta; PDRB adalah PDRB per kapita, MSJ adalah masjid, dan PSTR dan STR masing-masing adalah pesantren dan santri. Kemudian $\beta_{1} \beta_{2}$ dan $\beta_{3}$ masing- masing adalah koefisien estimasi tiga dimensi religiusitas keislaman tersebut. Selanjutnya e merupakan error estimasi. Terakhir, $i$ adalah daerah (kabupaten kota) ke- $i(1,2, \ldots 23)$, dan $\mathrm{t}$ adalah periode tahun ke-t, (2010, 2011..2017).

Agar koefisien estimasi dimensi religiusitas keislaman terhadap pertumbuhan ekonomi dapat diinterpretasikan secara lebih baik, maka masing-masing variabel ditransformasi dalam bentuk logaritma. Sehingga persamaaan 1 di atas dapat tuliskan kembali seperti dalam persamaan 2 .

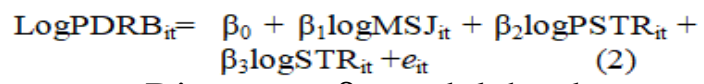

Dimana, $\beta_{0}$ adalah konstanta, $\log \mathrm{PDRB}_{\text {it }}$ adalah logaritma PDRB per kapita daerah ke i pada periode tahun ke-t, $\log \mathrm{MSJ}_{\text {it }}$ adalah logaritma mesjid di daerah $i$ pada periode tahun ke $t$, $\operatorname{logPSTR} \mathrm{R}_{\text {it }}$ adalah logaritma pesantren di daerah ke-i pada periode tahun ke-t, dan $\log \mathrm{STR}_{\text {it }}$ adalah logaritma jumlah santri di daerah i pada periode tahun t. Selanjutnya $\beta_{1} \quad \beta_{2}$ dan $\beta_{3}$ masing-masing adalah koefisien estimasi.

Penggunaan regresi panel dalam mengestimasi hubungan fungsional antar variabel menyediakan tiga pendekatan, terdiri dari common effect, fixed effect dan random effect (Muliadi \& Amri, 2019). Didasarkan pada Chow test dan Haussman test (tabel 2), pendekatan fixed effect dianggap memberikan hasil estimasi lebih akurat dibandingkan dengan dua pendekatan lainnya.

Guna mempertajam analisis tentang keterkaitan antara pertumbuhan ekonomi dan religiusitas keislaman, model regresi panel seperti dijelaskan di atas, kemudian dilengkapi dengan panel Granger causality test. Peralatan ekonometrik ini dapat memberikan informasi statistik yang berhubungan dengan arah kausalitas antar variabel (Roebroeck, 2015). Kausalitas antara religiusitas keislaman dimensi masjid dan pertumbuhan ekonomi misalnya, 
mengutip pendapat Dumitrescu \& Hurlin (2012), pengujian kausalitas dapat dilakukan melalui proses regresi seperti dalam persamaan 3 .

$$
\begin{aligned}
\operatorname{LogPDRB}_{\mathrm{i}, \mathrm{t}}= & \propto_{\mathrm{i}}+\sum_{\mathrm{k}=1}^{\mathrm{K}} \gamma_{\mathrm{ik}} \text { LPDRB }_{\mathrm{i}, \mathrm{t}-\mathrm{k}}+ \\
& \sum_{\mathrm{k}=1}^{\mathrm{K}} \beta_{\mathrm{ik}} \operatorname{LogMS}_{\mathrm{i}, \mathrm{t}-\mathrm{k}}+\varepsilon_{\mathrm{i}, \mathrm{t}}(3)
\end{aligned}
$$

dimana $\mathrm{i}=1, \ldots 0$, dan $\mathrm{t}=1, \ldots \mathrm{t}$,

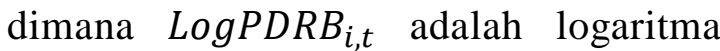
PDRB per kapita daerah i pada periode t, $\log M S J_{i, t}$ adalah jumlah mesjid di daerah i pada periode $\mathrm{t}$, dan $\mathrm{K}$ adalah rentang waktu dampak suatu variabel terhadap variabel lainnya. Indikasi adanya kausalitas didasarkan pada nilai p-value yang dihasilkan oleh output eviews, dengan ketentuan $p$-value $<0,05$ mengindikasikan adanya kausalitas. Sebaliknya ketika $p$-value $>0,05$ bermakna tidak terdapat kausalitas (Ghysels et al., 2016).

\section{HASIL DAN PEMBAHASAN}

Pertumbuhan ekonomi di Aceh berbeda berdasarkan daerah kabupaten kota. Perbedaan tersebut secara numerik terlihat dari adanya perbedaan PDRB per kapita masing-masing daerah. Sebagai daerah penerapan syariat Islam, tingkat religiusitas keislaman di Aceh juga berbeda berdasarkan kabupaten kota. Indikasi ini dilihat dari tiga dimensi religiusitas tersebut yang dalam hal ini ditunjukkan oleh jumlah masjid, pesantren dan santri. Menggunakan data gabungan antara data seri waktu 20102017, dan data silang 23 kabupaten kota, diperoleh hasil statistik deskriptif seperti

\begin{tabular}{|c|c|c|c|c|}
\hline $\begin{array}{l}\text { Parameter } \\
\text { Statistik }\end{array}$ & $\begin{array}{l}\text { PDRB per kapita } \\
\text { (Rp juta) }\end{array}$ & $\begin{array}{c}\text { Mesjid } \\
\text { (Unit per } 10.000 \\
\text { pddk) }\end{array}$ & $\begin{array}{c}\text { Pesantren } \\
\text { (Unit per } \\
20.000 \text { pddk) }\end{array}$ & $\begin{array}{c}\text { Santri } \\
\text { (Orang } \\
\text { per } \\
10.000 \\
\text { pddk) }\end{array}$ \\
\hline & \multicolumn{4}{|c|}{ Statistik deskriptif } \\
\hline Mean & 22,117 & 10 & 5 & 298 \\
\hline Median & 19,163 & 11 & 5 & 286 \\
\hline Maximum & 53,635 & 21 & 13 & 849 \\
\hline Minimum & 11,733 & 3 & 1 & 17 \\
\hline \multirow[t]{2}{*}{ Obs } & 184 & 184 & 184 & 184 \\
\hline & \multicolumn{4}{|c|}{ Koefisien korelasi } \\
\hline PDRB per kapita & 1 & & & \\
\hline Mesjid & -0.309 & 1 & & \\
\hline Pesantren & 0.038 & -0.169 & 1 & \\
\hline$\underline{\text { Santri }}$ & -0.159 & -0.167 & 0.551 & 1 \\
\hline
\end{tabular}
dalam Tabel 1.

Sumber: Output E-views
Tabel 1 di atas memperlihatkan statistik deskriptif masing-masing variabel. Secara rata-rata PDRB per kapita sebesar Rp22,117 juta per tahun. Berkaitan dengan religiusitas ke-islaman, rata-rata jumlah mesjid per 10.000 penduduk sebanyak 10 unit dengan rata-rata santri 298 orang. Selanjutnya rata-rata jumlah pesantren per 20.000 penduduk sebanyak 5 unit.

Model analisis yang digunakan untuk menganalisis pengaruh ketiga dimensi religiusitas keislaman terhadap pertumbuhan ekonomi adalah regresi panel. Model ekonometrika tersebut terdiri dari tiga pendekatan yakni common effect model, fixed effect model dan random effect model. Penentuan salah satu pendekatan yang mampu memberikan hasil estimasi terbaik, didasarkan pada Chow test dan Hausman test. Hasil uji tersebut seperti

\begin{tabular}{|c|c|c|c|c|}
\hline Pengujian & & $\begin{array}{c}\text { Nilai } \\
\text { statistik }\end{array}$ & p-value & $\begin{array}{l}\text { Kesim- } \\
\text { pulan }\end{array}$ \\
\hline Chow test & $\begin{array}{l}\text { Cross-sect } \\
\text { F-stat } \\
\text { Cross-sect } \\
X^{2} \text { stat }\end{array}$ & $\begin{array}{l}190,582 \\
610,056\end{array}$ & $\begin{array}{r}0,000 \\
0,000\end{array}$ & $\begin{array}{c}\text { Fixed effect } \\
\text { lebih baik }\end{array}$ \\
\hline Haussman test & $\mathrm{X}^{2}$-Stat & 12,313 & 0,000 & $\begin{array}{c}\text { Fixed effect } \\
\text { lebih baik }\end{array}$ \\
\hline
\end{tabular}
ditunjukkan dalam Tabel 2.

Sumber: Output E-views, 2020.

Tabel 2 di atas memperlihatkan nilai p-value yang dihasilkan melalui Chow test dan Haussman test lebih kecil dari 0,05. Hal ini memberikan kesimpulan statistik bahwa regresi panel pendekatan fixed effect dapat memberikan hasil estimasi yang lebih akurat dibandingkan dengan dua pendekatan lainnya.

Pengukuran religiusitas ke-Islaman dalam penelitian ini menggunakan tiga dimensi terdiri dari jumlah mesjid, pesantren dan santri. Penggunaan ketiga dimensi tersebut didasarkan pada kerangka pemikiran bahwa daerah dengan mesjid, pesantren dan santri relatif lebih banyak mengindikasikan bahwa tingkat religiusitas ke-Islaman di daerah tersebut relatif tinggi. Sebaliknya daerah dengan masjid, pesantren dan santri relatif sedikit dianggap memiliki tingkat religiusitas keislaman lebih rendah.

Hasil regresi panel sehubungan dengan pengaruh tiga dimensi religiusitas tersebut terhadap pertumbuhan ekonomi, 
Jurnal Ilmiah Ekonomi dan Bísnis

Vol. 18. No.1,Maret 2021 : 19-28

EISSN : $2442-9813$

ISSN : $1829-9822$

menghasilkan koefisien estimasi bernilai positif. Hal ini mengindikasikan bahwa kegiatan ekonomi masyarakat di Aceh secara positif terkait dengan religiusitas keislaman. Dengan kata lain, terjadinya perubahan dalam ketiga dimensi tersebut memberikan dampak positif terhadap peningkatan pendapatan masyarakat. Ringkasan hasil regresi panel seperti ditunjukkan dalam Tabel 3.

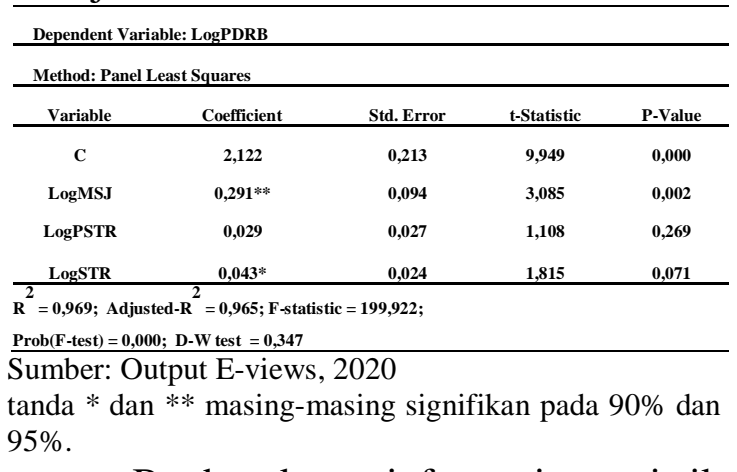

Berdasarkan informasi statistik dalam Tabel 3, maka hubungan fungsional antara pertumbuhan ekonomi dengan mesjid, pesantren dan jumlah santri seperti dalam persamaan 2 .

$\operatorname{LogPDRB}_{\mathrm{it}}=\quad 2,122+0,291 \mathrm{LogMSJ}_{\mathrm{it}}+0,029 \operatorname{LogPSTR}_{\mathrm{it}}$ $+0,043 \operatorname{LogSTR}_{\mathrm{it}}$

Keberadaan mesjid secara signifikan berpengaruh positif terhadap pertumbuhan ekonomi daerah, dengan koefisien estimasi sebesar 0,291 dan $p$ value $=0,002 \quad(<0,05)$. Hal ini mengindikasikan bahwa peningkatan jumlah mesjid secara signifikan berpengaruh terhadap peningkatan pertumbuhan ekonomi. Sebagaimana dijelaskan sebelumnya, pertumbuhan ekonomi dalam kajian ini diukur dengan menggunakan pendapatan per kapita. Sehingga hasil estimasi tersebut secara statistik menginformasikan bahwa eksistensi mesjid di suatu daerah secara signifikan berdampak pada pendapatan per kapita masyarakat di daerah tersebut. Adanya pengaruh mesjid terhadap pendapatan masyarakat mengindikasikan bahwa keberadaan mesjid memberikan dampak positif terhadap kegiatan ekonomi masyarakat. Temuan ini sejalan dengan temuan Durlauf et al. (2010) yang juga menyimpulkan bahwa agama yang ditandai dengan ketaatan pengikutnya menjalankan nilai-nilai keagamaan yang dianut berdampak positif terhadap perbaikan pendapatan. Keyakinan agama secara langsung mempengaruhi perilaku individu yang pada gilirannya mempengaruhi pertumbuhan ekonomi melalui pilihan individual (Barro \& McCleary, 2001).

Temuan ini konsisten dengan hasil penelitian Qayyum et al. (2019) yang membuktikan bahwa eksistensi rumah ibadah berpengaruh positif terhadap pembangunan ekonomi. Ketaatan masyarakat terhadap nilai-nilai dan normanorma agama berdampak terhadap pola hidup dan perilaku mereka termasuk dalam hubungannya dengan kegiatan ekonomi. Hasil penelitian ini juga mendukung temuan penelitian Ohlmann \& Huttel (2018) tentang dampak ekonomi religiusitas komunitas kristen di sejumlah negara Afrika yang menyodorkan bukti empiris bahwa religiusitas secara positif dan signifikan berhubungan dengan peningkatan pendapatan masyarakat. Sebaliknya, temuan ini bertolak belakang dengan kesimpulan penelitian Barro \& McCleary (2003) dengan kasus komunitas kristen yang mengungkapkan bahwa keberadaan gereja yang diiringi dengan meningkatnya kehadiran masyarakat di rumah ibadah tersebut berdampak negatif terhadap pertumbuhan ekonomi.

Keberadaan santri dalam suatu daerah juga secara positif dan signifikan berdampak terhadap pertumbuhan ekonomi, ditunjukkan oleh koefisien estimasi sebesar 0,043 dengan $\mathrm{p}$-value $=0,071(<0,10)$. Pada keyakinan $90 \%$, daerah dengan jumlah santri relatif lebih banyak memiliki pendapatan per kapita relatif lebih tinggi dibandingkan daerah dengan santri relatif sedikit. Dengan kata lain, perubahan jumlah santri di suatu daerah seiring dengan perubahan pendapatan per kapita masyarakat.

Selanjutnya pengaruh pesantren terhadap pertumbuhan ekonomi juga positif 
dengan koefisien estimasi sebesar 0,029. Namun tidak signifikan dengan $\mathrm{p}$ value $=$ 0,269 (> 0,05). Angka statistik ini mengindikasikan bahwa perkembangan jumlah pesantren di tertentu tidak berdampak secara nyata terhadap peningkatan pendapatan masyarakat di daerah tersebut. Hal ini tentunya tidak terlepas dari eksistensi pesantren sebagai lembaga pendidikan islam yang arah program pendidikanya lebih cenderung pada pembentukan akhlak dan penanaman nilai-nilai keagamaan bagi masyarakat.

Guna mempertajam analisis mengenai keterkaitan antara pertumbuhan ekonomi dengan jumlah mesjid, pesantren dan santri sebagai ukuran tingkat religiusitas ke-Islaman daerah, digunakan Granger causality test. Peralatan ekonometrik ini pada dasarnya berguna untuk menganalisis sejauhmana perubahan dalam suatu variabel pada periode terentu disebabkan oleh terjadinya perubahan dalam variabel variabel lain di masa lalu (Hasyim et al., 2019).

Hasil uji tersebut menunjukkan bahwa dalam horizon waktu 1 periode terdapat kausalitas satu arah dari jumlah mesjid dan santri ke pertumbuhan ekonomi, dan dari pertumbuhan ekonomi dan jumlah mesjid ke pesantren. Angka statistik ini menginformasikan adanya keterkaitan yang signifikan antara pertumbuhan ekonomi periode tertentu (t) dengan jumlah mesjid dan santri periode sebelumnya (t-1). Selanjutnya, perubahan jumlah pesantren dalam periode tertentu (t) juga secara signifikan disebabkan oleh perubahan dalam jumlah masjid dan pertumbuhan ekonomi periode sebelumnya (t-1).

Selanjutnya dalam horizon waktu 2 periode kausalitas satu arah eksis dari pertumbuhan ekonomi dan jumlah santri ke pesantren. Informasi statistik ini dapat maknai bahwa perkembangan jumlah pesantren pada periode tahun tertentu merupakan respon terhadap perubahan pendapatan masyarakat dan perkembangan jumlah santri dua tahun sebelumnya (t-2). Untuk lebih jelasnya mengenai Granger causality test seperti ditunjukkan dalam Tabel 4.

\begin{tabular}{|c|c|c|c|c|}
\hline \multirow{3}{*}{$\begin{array}{l}\text { Variabel } \\
\text { Endogen }\end{array}$} & \multicolumn{4}{|c|}{ Variabel Eksogen } \\
\hline & \multicolumn{4}{|c|}{ Lag 1} \\
\hline & LogPDRB & LogMSJ & LogPSTR & LogSTR \\
\hline \multirow[t]{2}{*}{ LogPDRB } & & {$[4,169]^{*}$} & {$[1,257]$} & {$[14,787]^{* * *}$} \\
\hline & 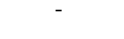 & $(\mathbf{0 , 0 4 3 )}$ & $(0,264)$ & $(\mathbf{0 , 0 0 0 )}$ \\
\hline \multirow[t]{2}{*}{ LogMSJ } & {$[0,293]$} & & {$[0,103]$} & {$[0,502]$} \\
\hline & $(0,589)$ & - & $(0,749)$ & $(0,479)$ \\
\hline \multirow[t]{2}{*}{ LogPSTR } & {$[6,331] * *$} & {$[3,345]^{*}$} & & {$[0,001]$} \\
\hline & $(0,013)$ & $(0,069)$ & - & $(0,986)$ \\
\hline \multirow[t]{4}{*}{ LogSTR } & {$[0,643]$} & {$[0,112]$} & {$[0,303]$} & \\
\hline & $(0,424)$ & $(0,738)$ & $(0,583)$ & - \\
\hline & \multicolumn{4}{|c|}{ Lag 2} \\
\hline & LogPDRB & LogMSJ & LogPSTR & LogSTR \\
\hline \multirow{2}{*}{ LogPDRB } & & {$[0,841]$} & {$[0,229]$} & {$[1,689]$} \\
\hline & 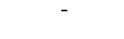 & $(0,434)$ & $(0,796)$ & $(0,189)$ \\
\hline \multirow[t]{2}{*}{ LogMSJ } & {$[1,298]$} & & {$[1,759]$} & {$[0,539]$} \\
\hline & $(0,276)$ & - & $(0,176)$ & $(0,585)$ \\
\hline \multirow{2}{*}{ LogPSTR } & {$[4,618]^{* *}$} & {$[1,391]$} & & {$[2,649]^{*}$} \\
\hline & $(0,012)$ & $(0,252)$ & 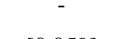 & $(0,074)$ \\
\hline \multirow[t]{4}{*}{$\operatorname{LogSTR}$} & {$[0,259]$} & {$[0,793]$} & {$[0,059]$} & \\
\hline & $(0,772)$ & $(0,455)$ & $(0,943)$ & - \\
\hline & \multicolumn{4}{|c|}{ Lag 3} \\
\hline & LogPDRB & LogMSJ & LogPSTR & LogSTR \\
\hline \multirow[t]{2}{*}{ LogPDRB } & & {$[0,731]$} & {$[1,045]$} & {$[1,711]$} \\
\hline & - & $(0,536)$ & $(0,376)$ & $(0,169)$ \\
\hline \multirow[t]{2}{*}{ LogMSJ } & {$[1,282]$} & & {$[1,269]$} & {$[0,314]$} \\
\hline & $(0,284)$ & - & $(0,289)$ & $(0,815)$ \\
\hline \multirow[t]{2}{*}{ LogPSTR } & {$[4,089] * *$} & {$[0,439]$} & & {$[2,088]$} \\
\hline & $(0,009)$ & $(0,725)$ & - & $(0,106)$ \\
\hline \multirow[t]{4}{*}{ LogSTR } & {$[0,577]$} & {$[0,675]$} & {$[0,216]$} &  \\
\hline & $(0,631)$ & $(0,569)$ & $(0,885)$ & - \\
\hline & \multicolumn{4}{|c|}{ Lag 4} \\
\hline & LogPDRB & LogMSJ & LogPSTR & LogSTR \\
\hline \multirow[t]{2}{*}{ LogPDRB } & & {$[0,409]$} & {$[0,908]$} & {$[1,147]$} \\
\hline &  & $(0,801)$ & $(0,463)$ & $(0,340)$ \\
\hline \multirow[t]{2}{*}{ LogMSJ } & {$[1,323]$} & & {$[1,106]$} & {$[1,237]$} \\
\hline & $(0,268)$ & - & $(0,359)$ & $(0,302)$ \\
\hline \multirow[t]{2}{*}{ LogPSTR } & {$[\mathbf{2}, 864]^{* *}$} & {$[0,285]$} & (n) & {$[2,668]^{* *}$} \\
\hline & $(\mathbf{0 , 0 2 8})$ & $(0,887)$ & - & $(\mathbf{0 , 0 3 8})$ \\
\hline \multirow[t]{2}{*}{ LogSTR } & {$[0,615]$} & {$[0,526]$} & {$[0,935]$} &  \\
\hline & $(0,653)$ & $(0,717)$ & $(0,448)$ & - \\
\hline
\end{tabular}

Sumber: Output E-views, 2020.

Angka dalam [ ] adalah nilai F statistik, dan ( ) adalah nilai p-value, tanda $*$ dan $* *$ masing-masing signifikan pada $90 \%$ dan $95 \%$.

Berdasarkan Tabel 4 di atas, maka untuk lebih jelasnya mengenai arah kausalitas antara ketiga dimensi religiusitas keislaman dengan pertumbuhan ekonomi dapat dilihat Gambar 1. Arah kausalitas antar variable

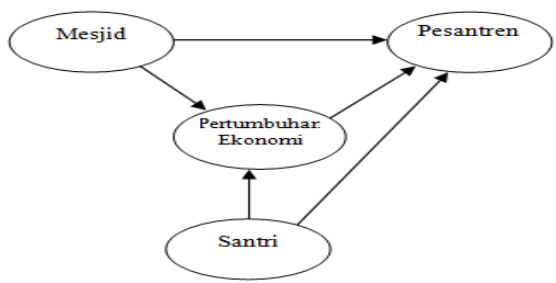

Gambar di atas memperlihatkan bahwa kausalitas satu arah dari mesjid ke pertumbuhan ekonomi dan pesantren. Hal ini mengindikasikan bahwa kenaikan 
Jurnal Ilmiah Ekonomi dan Bisnis

Vol. 18. No.1,Maret $2021: 19-28$

EISSN : $2442-9813$

ISSN : $1829-9822$

pendapatan masyarakat dan perkembangan pesantren di daerah tertentu merupakan respon terhadap perkembangan jumlah mesjid di daerah yang bersangkutan. Keberadaan mesjid tidak hanya berfungsi sebagai tempat ibadah bagi masyarakat, tetapi melalui mesjid juga terbentuk hubungan sosial antara sesama masyarakat yang pada gilirannya berdampak pada kegiatan ekonomi. Selanjutnya, keberadaan mesjid bagi masyarakat muslim juga dapat meningkatkan ketaatan mereka dalam beribadah dan pada gilirannya memperbaiki religiusitas ke-islaman mereka. Kondisi tersebut berdampak meningkatkan kesadaran masyarakat tentang pentingnya pesantren sebagai lembaga pendidikan non formal guna meningkatkan pemahaman masyarakat terhadap ilmu agama. Hal inilah yang menyebabkan adanya kausalitas satu arah dari perkembangan jumlah mesjid ke jumlah pesantren.

\section{KESIMPULAN DAN SARAN}

Secara umum, kajian terhadap pertumbuhan ekonomi menjadikan variabel-variabel ekonomi sebagai predictors pertumbuhan tersebut. Padahal aktivitas ekonomi dilakukan masyarakat dan pilihan-pilihan yang mereka buat dalam mendukung kehidupan mereka tidak hanya terkait dengan variabel ekonomi, tetapi juga dapat disebabkan oleh faktor lain seperti religiusitas.

Penelitian ini mengkaji dampak ekonomi religiusitas keislaman di Aceh. Dampak ekonomi yang dimaksudkan adalah pertumbuhan ekonomi daerah kabupaten kota yang diproxi dari pendapatan per kapita masyarakatnya. Mengoperasionalkan data panel kabupaten kota dalam periode 2010-2017, penelitian menemukan bahwa religiusitas keislaman dimensi mesjid dan santri secara signifikan mendorong pertumbuhan ekonomi. Sebaliknya, dimensi pesantren tidak berpengaruh terhadap pertumbuhan ekonomi.

Hasil uji kausalitas Granger mengindikasikan bahwa peningkatan pendapatan masyarakat merupakan respon terhadap perkembangan jumlah masjid dan peningkatan jumlah santri. Selain itu, perkembangan pesantren sebagai lembaga pendidikan islam, juga merupakan respon terhadap adanya peningkatan pendapatan masyarakat, dan perkembangan jumlah masjid dan santri.

Mengacu pada kesimpulan di atas, maka upaya untuk meningkatkan peran agama dalam mendukung memperbaiki kesejahteraan masyarakat di Aceh dapat dilakukan dengan memaksimalkan peran mesjid, pesantren dan santri. Pemerintah daerah di Aceh harus meningkatkan perhatian pada pembangunan sektor keagamaan. Pembangunan mesjid tidak hanya berfungsi sebagai tempat ibadah bagi masyarakat, tetapi memiliki dampak signifikan terhadap pertumbuhan ekonomi. Demikian juga halnya dengan keberadaan pesantren dan perkembangan santri juga memberikan kontribusi bagi perbaikan kehidupan masyarakat secara umum.

Penelitian ini telah meletakkan dasar kajian mengenai keterkaitan antara dimensi religiusitas keislaman dengan pertumbuhan ekonomi daerah kabupaten kota di Aceh. Peneliti akan datang yang tertarik untuk mengkaji hubungan fungsional antara variabel tersebut sebaiknya berupaya mengungkapkan saluran transmisi (transmission channel) pengaruh religiusitas keislaman terhadap kegiatan ekonomi masyarat. Sehingga dapat diketahui "melalui jalur mana" religiusitas keislaman berdampak pada kegiatan ekonomi dan pendapatan masyarakat.

\section{DAFTAR PUSTAKA}

Abu Raiya, H., Pargament, K. I., Mahoney, A., \& Stein, C. (2008). A psychological measure of islamic religiousness: Development and evidence for reliability and 
validity. The International Journal for the Psychology of Religion, 18(4), 291-315. doi:10.1080/1050861080222927 0 .

Adegboye, F.B., Osabohien, R., Olokoyo, F.O., Matthew, O., \& Adediran, O. (2020). Institutional quality, foreign direct investment, and economic development in subSaharan Africa. Humanit Soc Sci Commun 7, 38 (2020). https://doi.org/10.1057/s41599020-0529-x

Alesina, A., Ozler, S., Roubini, N., \& Swagel, P. (1996). Political instability and economic growth. Journal of Economic Growth, $1(2)$, doi:10.1007/bf00138862

Amri, K. \& Aimon, H. (2017). Pengaruh pembentukan modal dan ekspor terhadap Pertumbuhan ekonomi Indonesia, Economac: Jurnal Ilmiah Ilmu Ekonomi 1 (1), 1-16.

Amri, K. (2017). Analisis pertumbuhan ekonomi dan ketimpangan pendapatan: Panel data 8 provinsi di Sumatera, Jurnal Ekonomi dan ManajemenTeknologi, 1(1), 1-11.

Barro, R. J, \& McCleary, R. M. (2001). Religion and economic growth, Washington DC: National Bureau of Economic Research, NBER Working Paper 9682.

Barro, R. J., \& McCleary, R. M. (2003). Religion and economic growth across countries, American Sociological Review, 68(5), 760781.

Barro, R. J., \& McCleary, R. M. (2003). Religion and economic growth across countries, American Sociological Review, 68(5), 760781.

Basedau, M., Gobien, S., \& Prediger, S. (2018). The multidimensional effects of religion on socioeconomic development: A review of the empirical literature. Journal of Economic Surveys, 32(4), 1106-1133. doi:10.1111/joes.12250

Becker, S. O., Nagler, M., \& Woessmann, L. (2017). Education and religious participation: city-level evidence from Germany's secularization period 1890-1930. Journal of Economic Growth, 22(3), 273311. doi:10.1007/s10887-017$9142-2$

Campante, F., \& Yanagizawa-Drot, D. (2013). Does religion affect economic growth and happiness? Evidence from Ramadan, Research Working Paper, No. 13-052.

Casimir, A., Nwaoga, C. T., \& Ogbozor, R. F. C. (2014). Religion, violence, poverty and underdevelopment in west Africa: Issues and challenges of Boko Haram phenomenon in Nigeria, Open Journal of Philosophy, 4(1), 59-67.

Castaño, M.-S. (2007). The Influence of Socioeconomic Factors on Economic Growth. International Advances in Economic Research, 13(2), 139-145. doi:10.1007/s11294-007-9082-2

Dumitrescu, E.-I, \& Hurlin, C. (2012). Testing for Granger non causality in heterogeneous panels, Economic Modelling 29,1450-1460.

Durham, J. B. (1999). Journal of Economic Growth, 4(1), 81-111. doi:10.1023/a:1009830709488

Durlauf, S. N., Kourtellos, A., \& Tan, C. M. (2010). Is God in the Details? A Reexamination of the Role of Religion in Economic Growth," University of Cyprus Working Papers in Economics 11-2010, University of Cyprus Department of Economics.

Ghysels, E., Hill, J. B., \&Motegi, K. (2016).Testing for Granger causality with mixed frequency data. Journal of Econometrics, 
Jurnal Ilmiah Ekonomi dan Bísnis

Vol. 18. No.1,Maret 2021 : 19-28

EISSN : $2442-9813$

ISSN : $1829-9822$

192(1), 207-230.

doi:10.1016/j.jeconom.2015.07.0

07.

Hasyim, S., Zulhilmi, M., \& Amri, K. (2019). Is there a causality relationship between law enforcement, crime rates, and economic growth? An empirical evidence from western Indonesia, Regional Science Inquiry 11 (3), 95-109.

Islam, M. S. (2020). Human Capital and Per Capita Income Linkage in South Asia: A Heterogeneous Dynamic Panel Analysis. Journal of the Knowledge Economy. doi:10.1007/s13132-020-006371.

Jana-Masri, A., \& Priester, P. E. (2007). The Development and Validation of a Qur'an-Based Instrument to Assess Islamic Religiosity: The Religiosity of Islam Scale. Journal of Muslim Mental Health, 2(2), 177-188. doi:10.1080/1556490070162443 6.

Kanu, S.I \& Ozurumba, B. A. (2014). Capital formation and economic growth in Nigeria, Global Journal of Human-Social Science: Economics, 14(4): 43-58.

Martin, W. (2019). Economic Growth, Convergence and Agricultural Economics. Agricultural Economics. doi:10.1111/agec. 12528

McCleary, R. M., \& Barro, R. J. (2006) Religion and Economy, Journal of Economic Perspectives, 20(2), $49-72$

Muliadi, \& Amri, K. (2019). Infrastruktur jalan, belanja modal dan kesempatan kerja: Bukti data panel kabupaten kota di Aceh, Jurnal Manajemen dan Sains 4 (2), 334-341.

Narayanan, Y. (2016). Religion, Sustainable Development and
Policy: Principles to Practice. Sustainable Development, 24(3), 149-153. doi:10.1002/sd.1616

Ohlmann, P., \& Hüttel, S. (2018). Religiosity and household income in Sekhukhune. Development Southern Africa, 35(2), 179-193. doi:10.1080/0376835x.2018.14264 44.

Padhi, S. P. (2018). Importance of Employment Growth: A Perspective on Technological Progress. The Indian Journal of Labour Economics, 61(2), 401409. doi:10.1007/s41027-018$0135-2$

Qayyum, U., Anjum, S. \& Sabir, S. (2019). Religion and economic development: new insights. Empirica (2019). https://doi.org/10.1007/s10663019-09456-3.

Roebroeck, A. (2015). Granger Causality. Brain Mapping, 593-597. doi:10.1016/b978-0-12-3970251.00337-7

Sarin, V., Mahapatra, S. K., \& Sood, N. (2020). Export diversification and economic growth: A review and future research agenda. Journal of Public Affairs. doi:10.1002/pa.2524

Wang, Q., \& Lin, X. (2014). Does religious beliefs affect economic growth? Evidence from provincial-level panel data in China, China Economic Review 31, 277-287 